\title{
On the Tricks Alveolar Epithelial Cells Play to Make a Good Lung
}

\author{
Ewald R. Weibel \\ Institute of Anatomy, University of Bern, Bern, Switzerland
}

Building a good lung, capable of efficient gas exchange between air and blood, poses a number of conflicting problems for physiology and cell biology. One of these is the complex architecture that allows dynamic functional integration of the lung's structural elements (1); another is the role of cells in making a very thin and yet robust air-blood barrier, the topic of this essay. From a physiological perspective, the air-blood barrier must not only be very thin, measuring no more than a few tenths of a micrometer, but also of very large expanse, over $100 \mathrm{~m}^{2}$ in the human lung $(2,3)$. However, it must be built of biologically active cells, capable of selfmaintenance and self-renewal, as well as serving several functions beyond being a passive diffusion barrier. This holds particularly for the alveolar epithelium that forms the external sheet of the barrier (4).

In the age of molecular cell biology, fascinating discoveries have advanced our understanding of the biology of these cells, obtained in sophisticated studies partly in vivo, but for a large part in vitro (4-13). It is, however, important to also consider the exceptional conditions under which these cells develop and are sustained in the complex architecture of the integral functioning lung (1). In that view, the alveolar epithelium deserves particular attention, because it must form and secure the very large surface of the air spaces.

The epithelial covering of the alveolar capillaries is so extraordinarily thin that it was long believed by many prominent histologists that the capillaries were "naked like a wound" $(14,15)$, as light microscopy could not reveal a continuous lining by epithelial cells. It was the pioneer in electron microscopy, Frank Low

(1911-1998) who showed, in 1953, that the alveoli in mice and humans were lined by an uninterrupted epithelium made of two cell types: a "large" cuboidal cell with features of a secretory cell, and a "small" squamous cell that lined the surface of capillaries with very thin cytoplasmic leaflets (16). Low called the squamous cells the type I cells and the cuboidal cells the type II cells, designations still customary today. That settled the issue of a complete epithelial lining of alveoli, and it was soon accepted, even by the former proponents of a "naked" surface (17).

\section{Basic Histological Features of the Alveolar Lining}

Of the two cells that constitute the alveolar epithelium, the squamous type I cells cover $95 \%$ of the alveolar surface. As shown in Figure 1A, this cell has a central nucleus surrounded by a small amount of perinuclear cytoplasm, from which a very attenuated cytoplasmic leaflet extends peripherally to cover the capillaries. The perinulear cytoplasm contains a few organelles, such as small mitochondria and some endoplasmic reticulum with ribosomes. The leaflets that extend peripherally are bounded by two membranes: the basal cell membrane that is attached to the epithelial basement membrane, and the apical cell membrane that forms the surface toward the alveolus (Figure 1B). The thin layer of cytoplasm separating the two membranes contains cytoskeletal fibrils, some microtubules, membrane vesicles for transcellular transport, and few other constituents. The epithelium is a confluent mosaic of cells, which come into close contact with their immediate neighbors at their lateral cell membranes, the narrow band of membrane between the apical and basal membranes (Figure 1B). Here, the adjacent cells are tied together and the intercellular space is sealed at the apical edge by a tight junction (Figure 1B). Note that the capillary endothelial cells show very similar properties and nearly identical intercellular junctions (Figure 1B).

The cuboidal type II cell (Figure 1C) shows the characteristics of a secretory cell with lamellar bodies, the secretory granules of surfactant phospholipid (18), and an endoplasmic reticulum that serves the production of surfactant apoproteins $(19,20)$. The cell is integrated into the epithelium by broad intercellular junctions with type I cells at the lateral membranes with a tight junction at the apical edge (Figure 1C).

These basic structural characteristics of alveolar epithelial cells are also found in cell cultures derived from isolated type I and type II cells $(5,7,21,22)$.

\section{What Is the Problem? Complex Architecture of an Epithelium}

The problem with this simple description is that it does not consider the topology of the alveolar structures that form the substrate on which this epithelium develops, where we find very few cell bodies indeed on the large alveolar surface (Figure 2). In this section of two alveoli of a dog lung, we find a total of nine cell bodies with a nucleus: two type I cells, two type II \footnotetext{
Bern 9, Switzerland. E-mail: weibel@ana.unibe.ch

Am J Respir Crit Care Med Vol 191, Iss 5, pp 504-513, Mar 1, 2015

Copyright (c) 2015 by the American Thoracic Society

DOI: 10.1164/rccm.201409-1663OE

Internet address: www.atsjournals.org
}

(Received in original form September 15, 2014; accepted in final form November 4, 2014)

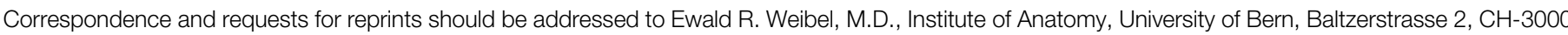



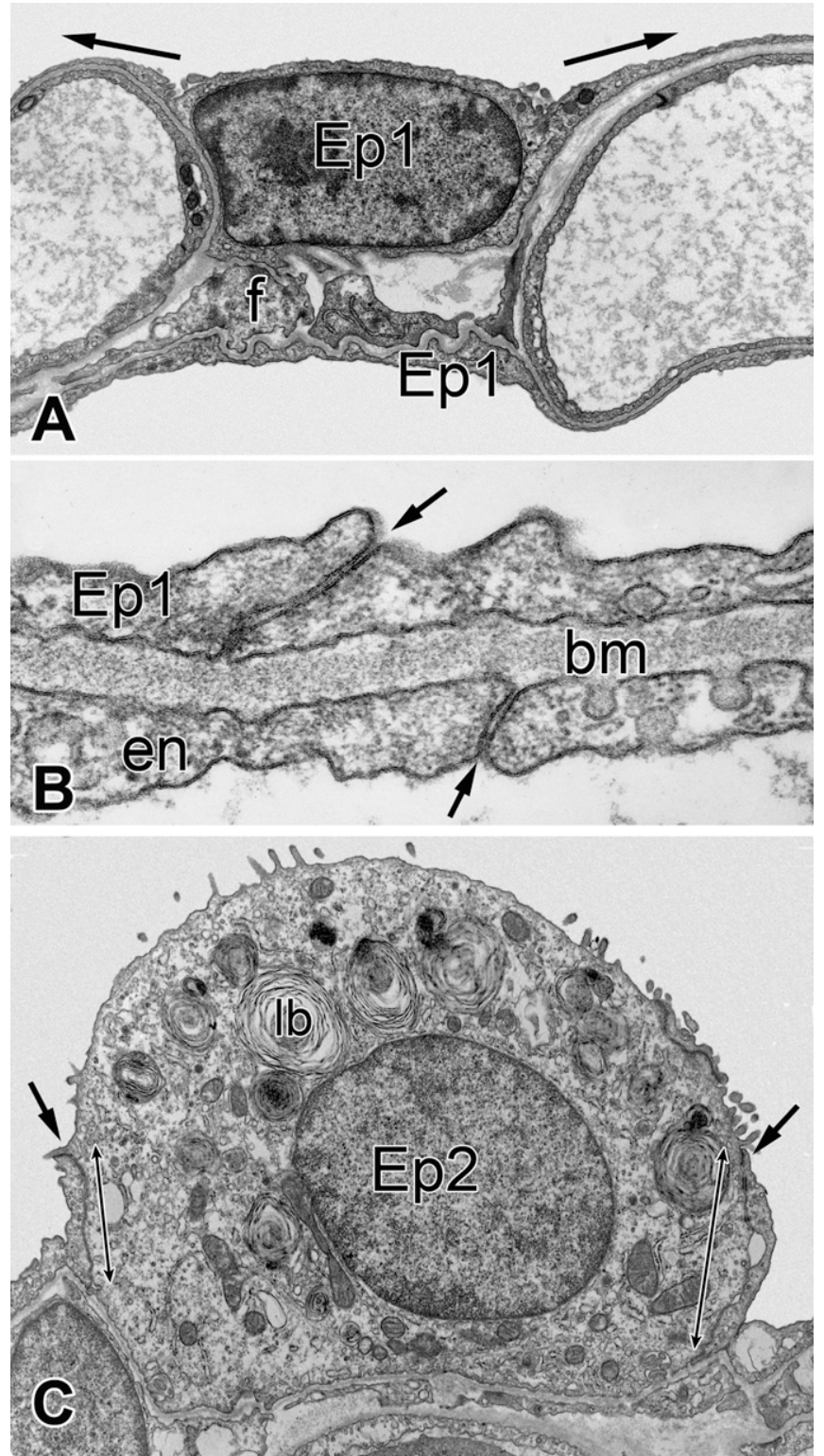

Figure 1. Basic features of alveolar epithelial cells. (A) Type I cell (Ep1) sitting in a niche of a capillary mesh and extending a thin cytoplasmic leaflet to form the air-blood barrier (long arrows). Interstitial space with fibroblast (f) separates this cell from type 1 cells lining the lower surface (reprinted by permission from Reference 43). (B) Higher-power view of the cytoplasmic leaflets of type I epithelial and endothelial cells (en) separated by fused basement membranes (bm) in thin part of barrier. Arrows point to intercellular junctions with tight junction in both cell layers. (C) Type II alveolar epithelial cell (Ep2) is a cuboidal cell with a cytoplasm rich in organelles related to the production of surfactant elements, such as phospholipids in lamellar bodies (Ib) and apoproteins. Note extended lateral membrane (double-headed arrows) with junctional complex between type II and type I cells (heavy single-headed arrows).

cells, four endothelial cells, and one macrophage. The situation is very similar in the human lung, as Crapo and coworkers showed (23): the epithelium of each of the 400 million human alveoli covers, on average, an area of $220,000 \mu \mathrm{m}^{2}$, and is made of 40 type I cells and 77 type II cells, but the type I cells make up over $95 \%$ of the surface. As a consequence, each type I cell covers, on average, a surface area of about $5,100 \mu \mathrm{m}^{2}$, a very large value, not found in any other tissue. Looking at an alveolar wall, this means that one type 1 cell would cover some 40 capillary meshes, an area roughly $80 \mu \mathrm{m}$ across. Figure 3 shows a scanning electron micrograph of the alveolar surface of a human lung. The capillaries are seen as bulging tubes, and we see two type II cells with their rim of microvilli sitting in niches of the capillary network. Near an alveolar pore, we notice a spherical bulge that corresponds to the cell body of a type I cell. The arrowheads point to a fine ridge that corresponds to the small lip that protrudes at the apical end of an intercellular junction (Figure 1B). So this ridge outlines the apical cytoplasmic plate of this type I cell: it extends over something like 14 capillary meshes and measures about $1,300 \mu \mathrm{m}^{2}$-about onequarter of what an average type I cell should cover.

As such, there appears to be a large discrepancy between the number of cell bodies of type I cells and the size or number of cytoplasmic plates. This fact was noted by Albert Kölliker in 1881 on specimens, such as that shown in Figure 4: staining the terminal bars with silver nitrate, Kölliker saw that there is a wide variation in the size of the cytoplasmic patches of epithelial cells, many devoid of an evident nucleus; hence Kölliker's conclusion that these must be "non-nucleated plates" of cytoplasm (24).

It turns out that this was an erroneous conclusion. Type I cells are not simple squamous cells, as the standard epithelial model predicts. Figure 5 shows two type 1 cells that sit in a niche of the capillaries and form the typical cytoplasmic leaflets that line the alveolar wall on the upper side, just as that in Figure 1A; but then they penetrate across the alveolar septum to form another set of cytoplasmic leaflets on the lower side of the septum. So these cells are related to at least two cytoplasmic plates each, one for each side of the septum. But that is not all. Figure 6 shows two cases where the type I leaflet extends across the septum to form linings on both sides in niches where there is no cell body. This suggests that one type I cell nucleus can be connected to several apical patches of varying size, as shown schematically in Figure 7. This now explains Kölliker's nonnucleated plates as those apical patches that are (seemingly indirectly) served from the perinuclear region through the stalks that crisscross the septum (25), and so they are not actually nonnucleated. 


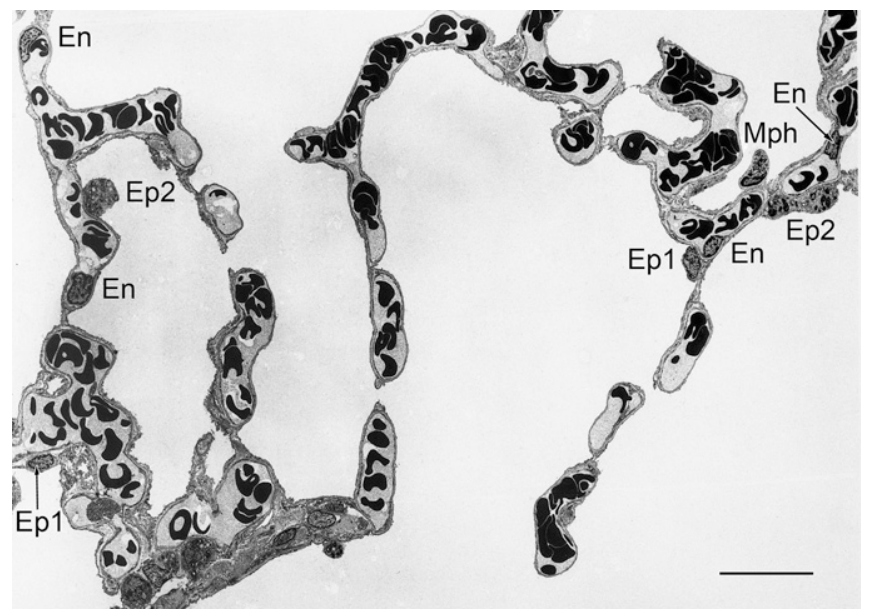

Figure 2. Low-power view of the section of a couple of alveoli in a dog lung where very few cell bodies with a nucleus are seen associated with a very large surface outline: two type I cells (Ep1), two type II cells (Ep2), four endothelial cells (En), and one macrophage (Mph). Scale bar $=20 \mu \mathrm{m}$.

\section{The Complex Substrate of the Alveolar Septa}

This very unusual cell architecture is made possible by the design of the supporting scaffold of the alveolar septa. This scaffold is formed by the dense alveolar capillary network supported by a lattice of connective tissue fibers as the septal segment of the lung's fiber continuum, which spreads the capillaries on a very large surface, while allowing this surface to be well ventilated from the alveolar duct system $(1,26)$. This structure evolves gradually during fetal and postnatal development and growth. The airways evolve from tubular to saccular by transforming the epithelium from a cuboidal to a mosaic structure with type I and II cells, and associating capillaries with the base of the epithelium. In the final step, alveoli are formed by lifting septa with a free edge from the saccular walls, thus forming alveolar ducts surrounded by a sleeve of densely packed alveoli (27-31).

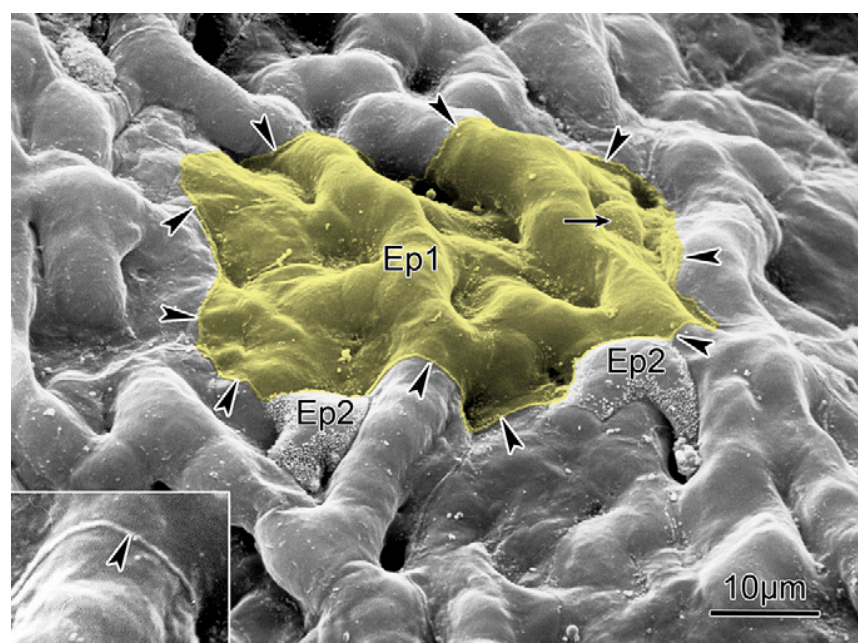

Figure 3. Scanning electron micrograph of the alveolar surface of a human lung showing protruding capillaries and two type II cells (Ep2) sitting in niches and characterized by a rim of microvilli.

Small arrow points to cell body of a type I cell (Ep1) that covers several capillary meshes (yellow); the boundary of its cytoplasmic leaflet is marked by arrowheads outlining a small lip of the cell junction between adjoining cells (inset, compare Figure 1B). The surface area covered by this cytoplasmic leaflet is $1,300 \mu \mathrm{m}^{2}$. Scale bar $=10 \mu \mathrm{m}$.

In this process, the capillaries are reduced from a double to a single network in the alveolar septa (32), and the loose mesenchyme is reduced to a slim meshwork of connective tissue fibers and fibroblasts anchored in the axial fiber system of alveolar ducts and in the peripheral fibers leading to the pleura (1).

In the course of this development the alveolar type I epithelial cells become more and more extended and attenuated to form, together with the endothelial cells, the very thin air-blood barrier. It is in this process of transformation of alveolar septa that the complex structure of type I cells develops, facilitated by the fact that the core of the septa, formed by capillaries and connective tissue, is a loose structure (Figure 8). In the meshes of the capillary network, where fibers cross from one side of the septum to the other, gaps may occur in the substrate of the epithelium. This allows the expansion of the type I cell from one side of the septum to the other, either by the formation of interalveolar pores (Figures 8 and 9), or by sending a cytoplasmic stalk across the septum to coat the other surface, as exemplified in Figures 5 and 6.

At this point, it is important to note that the alveolar epithelial basement membrane is formed in the process as the joint product of the alveolar epithelial cell and the extracellular matrix (33), and thus also serves as the boundary membrane of the interstitial matrix. The epithelial cell's basal membrane initiates the generation of the basement membrane through specific membrane proteins - the integrins - which bind to elements of the basement membrane, such as laminin, by which the epithelial cell now becomes tightly bound to the connective tissue matrix (33). Where the epithelium lies directly over the capillary, the two basement membranes can fuse (Figure 1B). The epithelial basement membrane also tightly follows the epithelial cytoplasmic extensions that cross the septum (Figures 5 and 6).

I have discussed this here in some detail, because it is of importance for understanding the complex nature of the branched type I cells. The polarity of epithelial cells is primarily determined by the basal cell membrane, because the integrins control not only the basement membrane formation, but also the intracellular basal-apical orientation by recruiting, through their intracellular 


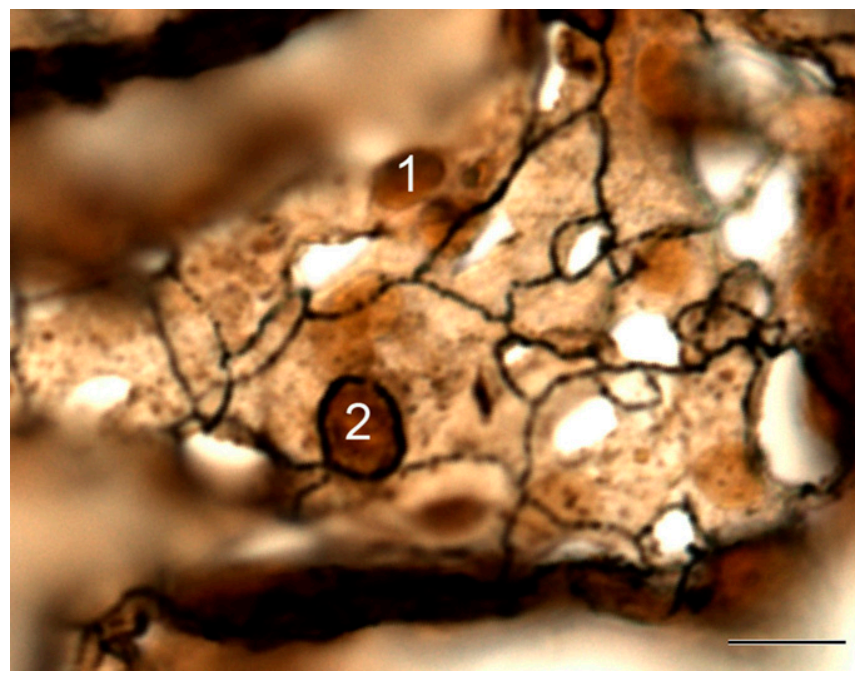

Figure 4. Light micrograph of a thick section of cat lung where terminal bars were stained with silver nitrate. "1" and "2" mark the nucleus of a type I and a type II cell, respectively. Scale bar =10 $\mu \mathrm{m}$. domain, an array of factors that control adhesion and organization of the cytoskeletal elements, microtubules, and actin fibrils, among others, that then determine the structure of the apical cytoplasm and membrane, and, indirectly,
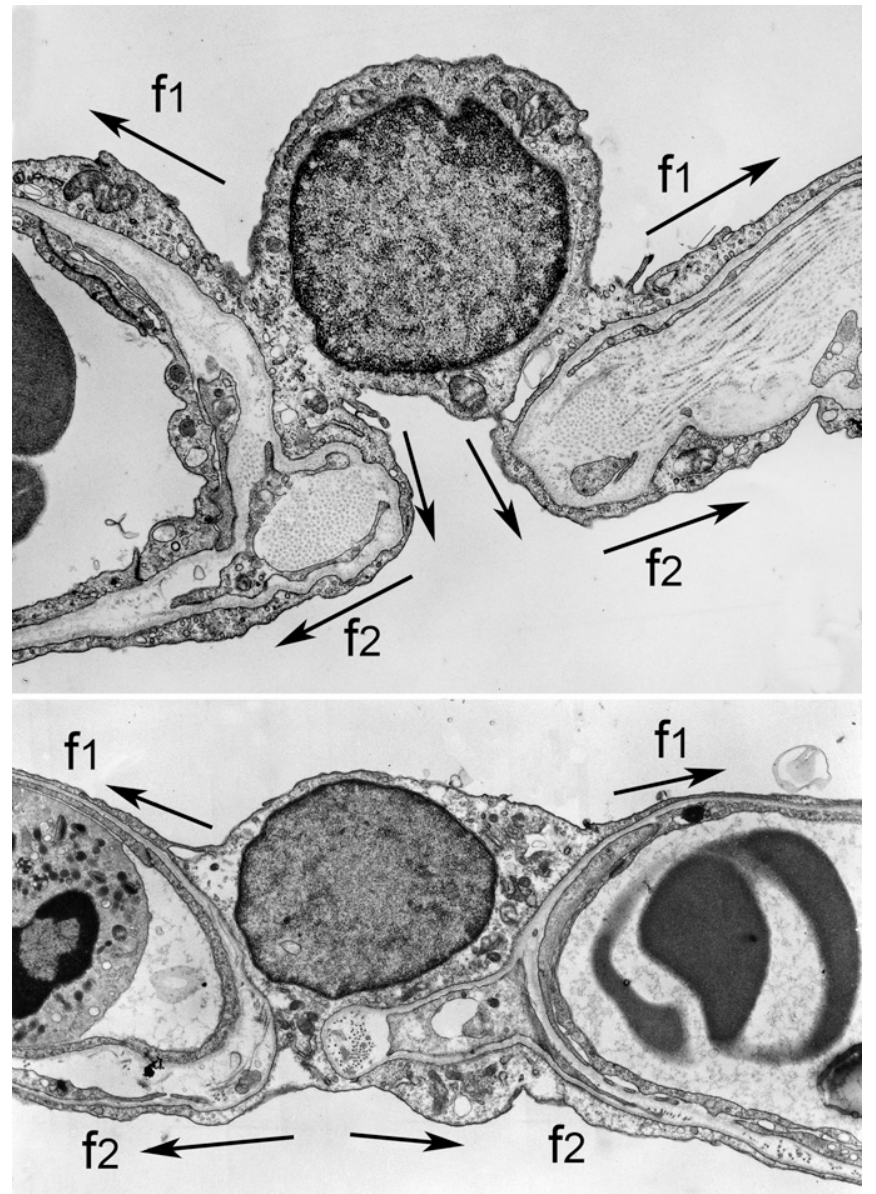

Figure 5. Two type I cells sitting in a capillary niche forming a cytoplasmic leaflet on the upper side of the septum (f1 arrows) and extending across the septum to form a second leaflet (f2 arrows) in the lower alveolus (monkey lung). Reprinted by permission from Reference 24. the formation of junctional complexes $(34,35)$. In that respect, it is now most important to note that, for each type I cell, the basal cell membrane and the associated epithelial basement membrane are one continuous structure, irrespective of the branching of cytoplasmic stalks and leaflets across the alveolar septum and back (Figure 7B); note that the average area of a type I cell in the human lung of $5,100 \mu \mathrm{m}^{2}$ indeed refers to the extension of the cell's basal membrane (23). The "fragmentation" of the cell into several apical plates thus concerns the apical cell membrane with its associated cytoplasmic structures and the junctional complexes with terminal bars: the cell is branched, but the basal cell membrane forms the common platform. The question is how this is compatible with the concept that the basal-apical polarity and the structure of the apical plate are controlled from the basal membrane area (34). These mechanisms are presumably determined by cross-talk of the apical plate processes with the basal membrane (36).

It is interesting to note that type II cells can also cross the alveolar septum to discharge their secretory products to more than one alveolus. Figure 10 shows a type II cell that sits at the junction of three septa; its bottom apical membrane secretes into the bottom alveolus, whereas the upper apical surface reaches two alveoli, because it is located at the edge of an alveolar pore. Note that the basal membrane of this cell forms a broad "belt" around the waist of the cell body: the basal cell membrane is again one continual surface, whereas the apical cell membrane has two distinct areas, the rim of which is formed by a strip of lateral cell membrane with its junctional complex formed with the attached type I cells.

How does this come about? Is it just an opportunistic behavior of cells spreading on a substrate with holes that allow spreading to the other side? Or are we dealing with a specific phenotype, particularly with the type I cells? These questions are open, but there are some observations that would tend to favor the notion of type I cells as specific phenotype. One of these is that the average area covered by one type I cell is species and body size independent: it is estimated at $5,100 \mu \mathrm{m}^{2}$ in humans of $76 \mathrm{~kg}$, $4,000 \mu \mathrm{m}^{2}$ in the baboon $(29 \mathrm{~kg}), 5,300 \mu \mathrm{m}^{2}$ in the rat $(0.36 \mathrm{~kg})$, and $5,200 \mu \mathrm{m}^{2}$ in the shrew (2.5 g) (23, 37-39). 


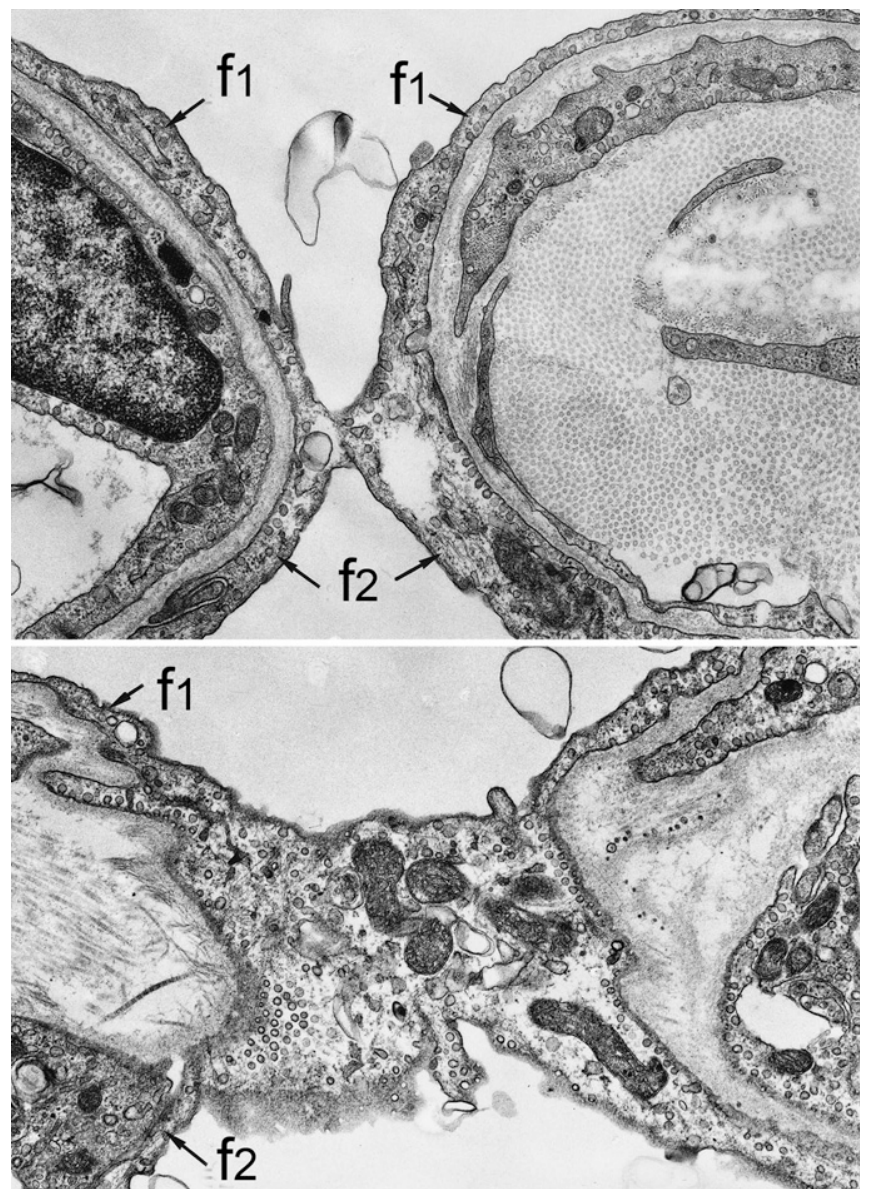

Figure 6. Cytoplasmic leaflets can extend across the septum independent of the perinuclear region to form the lining on both sides of the septum (f1 and f2). Reprinted by permission from Reference 24.

\section{Functional Implications of Type I Cell Architecture}

Drastically reducing the number of epithelial cells is of great physiological importance, as it contributes to building a very thin air-blood barrier $(40,41)$. However, this brings problems in adequately serving not only the maintenance of these delicate cell extensions, but also the operation and fueling of their multiple functions, apart from merely constituting a passive diffusion barrier (4). This requires the transfer of agents from the region of the nucleus through narrow cytoplasmic spaces. By breaking the coverage area of one cell into several smaller areas connected to the perinuclear area by cytoplasmic stalks, the transfer distances to peripheral parts are significantly reduced by about a factor of three, as the cell covers a large surface within a limited tissue volume. So to design the type I cells as branched cells strikes a compromise between two conflicting functional requirements-to keep the leaflets thin and still allow a large surface to be served metabolically-clearly an attempt to find an optimum design.

This is an intuitive interpretation, but is there evidence to support this? Let us consider what we can learn from comparative physiology by looking at how this problem is solved at the extreme of gas exchange performance. This is found in the Etruscan shrew (Suncus etruscus), one of the smallest mammals, weighing a mere $2.5 \mathrm{~g}$. The small size causes the metabolic rate to be extremely high, on the order of $0.3 \mathrm{ml} \mathrm{O} / 2 / \mathrm{min} / \mathrm{g}$ body mass-about 100 times higher than in humans. This shrew's heart rate is over 1,000 beats per minute, and the respiratory rate is 300 per minute $(42-44)$. To allow for such a high rate of $\mathrm{O}_{2}$ uptake, the gas exchanger of the Etruscan shrew is extraordinarily dense in that the capillaries occupy about $15 \%$ of the parenchymal volume (Figure 11A); alveoli are tiny, and the air-blood barrier is much thinner than in any other mammalian lung. Type I epithelial cells sit in the capillary meshes, and show an exceptionally high degree of branching of the cytoplasmic leaflets. In the case shown in Figure 11B, leaflets emanating from this cell form the lining of four adjacent capillaries on both sides, and they are connected to the nucleus with very narrow stalks. The principle of branched epithelial cells is here evidently pushed to the extreme, suggesting that, indeed, this principle serves the construction of a very efficient gas exchanger with an extremely thin, but well served, barrier.

\section{There Is a Price to Everything}

To coat $95 \%$ of the surface of a human alveolus with no more than 40 type I cells is an extraordinary, in fact, singular achievement. By breaking this large area into a number of smaller patches connected to the main cell body by cytoplasmic stalks, the type I cell is made robust to cope with multiple "ordinary" challenges to its integrity by facilitating traffic of cell constituents needed for maintenance of membranes, et cetera, even to the remote parts of the cell. Nevertheless, type I cells are especially vulnerable and likely to be damaged or even destroyed by, for instance, toxic influence, one well known case being $\mathrm{O}_{2}$ poisoning $(45,46)$, or in diseases, such as acute lung injury due to sepsis (47). In all these instances, it is found that type I cells cannot regenerate directly, but must be replaced by the proliferation of some stem cells, essentially type II cells, so that the repaired surface is now first lined by cuboidal cells that then can, in due time, transform or transdifferentiate into squamous type I cells $(45,48-50)$.

The price for this extraordinary architecture of type I cells is the loss of capacity for self-renewal by mitotic proliferation. This was first shown by Evans and colleagues (49) in studies of cell renewal in rat lungs after mild damage by $\mathrm{NO}_{2}$ exposure: nuclei of proliferating cells were labeled with tritiated thymidine, which is incorporated into the DNA during the prophase; in mitosis, it is transferred to the two daughter nuclei, and can be detected by autoradiography. Figure 12 shows that, in the first hour after injection 


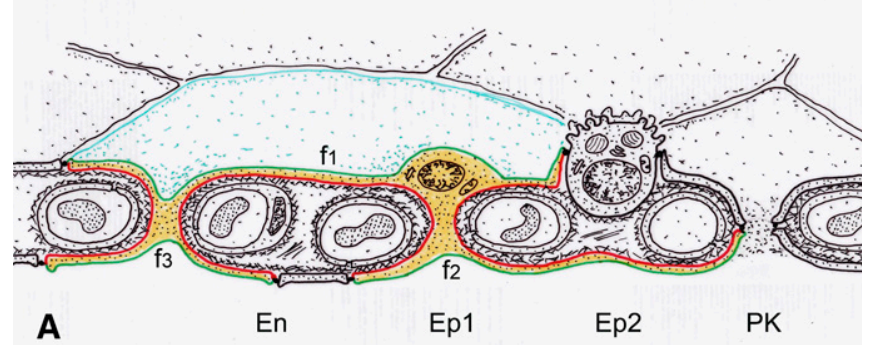

A

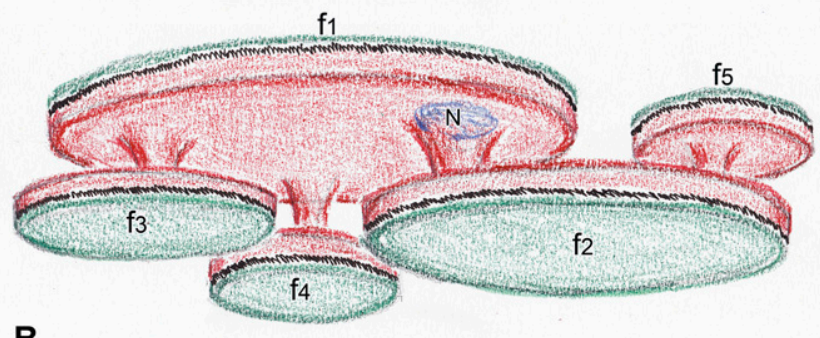

B

Figure 7. (A) Diagram of section of alveolar septum with branched type I cell (yellow) forming the cytoplasmic plates: $\mathrm{f} 1$ (comprising the nucleus) and $\mathrm{f} 2+\mathrm{f} 3$ (connected with stalks to the nuclear area). The apical cell membrane is shown in green and the basal membrane in red, separated by the terminal bar (black dots). (B) Topological diagram of this type I cell, in bottom-up view, showing the connection of the apical cytoplasmic facets (f2 to f5) by stalks to $f 1$ and the nucleus (N). Note that the basal cell membrane (red) is a continuum, whereas the apical membrane (green) is fragmented into facets. The black bands represent the terminal bars on the lateral surfaces. En, endothelial cell; Ep1 = type I epithelial cell; Ep2 = type II epithelial cell; PK = pore of Kohn.

of the label, almost $90 \%$ of type II cells had incorporated thymidine, thus preparing for cell division, but none of the type I cells had (49). Two days later, the fraction of labeled type II cells had declined to $50 \%$, and $35 \%$ of the type I cells were labeled, and this remained unchanged for the next 2 weeks. This is strong evidence that the repair of the alveolar epithelium after this mild damage was achieved by proliferation and transdifferentiation of type II cells, as had been found in recovery from oxygen poisoning (45), and not by proliferation of type I cells. This pattern is not limited to the adult lung, but appears to also be prevalent during postnatal development $(12,51,52)$. Figure 13 shows that, in the fast growing postnatal rat lung, type II cells took up thymidine, but there were no labeled type I cells at any stage in the first 3 weeks of postnatal growth; the increase in the number of type I cells could be

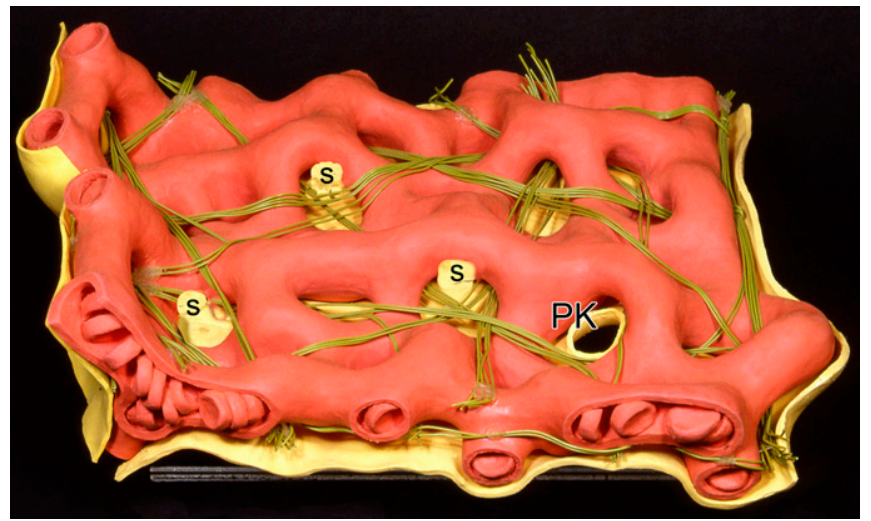

Figure 8. Model of alveolar septum with capillary network (red), fiber meshwork (green), and type I epithelial cell shown on bottom of septum (yellow). Note alveolar pore of Kohn (PK) in a capillary mesh, and three putative stalks (s) in other meshes.

accounted for by the proliferation and transdifferention of type II cells (52). Note also that, during the third week, the alveolar surface increased much more than the number of type I cells, suggesting that the latter were expanding their area by a factor of two. That type II cells are precursors of type I cells in the developing lung has recently been confirmed in mice by a molecular approach (12). So it appears that the type II cells constitute a population with long-term alveolar stem cells $(10,12,53)$ that can self-renew and, in part, differentiate to type I cells; there is some evidence that only a part of this population may be true stem cells $(11,12)$.

Why can differentiated type I cells not undergo mitotic division? This may well have to do with their complex topology with multiple apical plates. When an epithelial cell goes into mitosis, it must round up its shape to allow the mitotic spindle to develop properly, followed by symmetric division of the cell body with all its constituents and membranes into two equal parts. In this process, epithelial cells maintain their intercellular junctions, as well as their attachment to the epithelial basement membrane, so as to ensure proper insertion of the daughter cells into the epithelium (54). This is possible with type II cells, but not with the ramified type I cells with their multiple apical plates, where the intercellular junctions are located: no sensible division plane could be achieved (55). Of course, it is intriguing that this should even be the case in the fast-growing postnatal lung (52), but this may be a further argument that type I cells may, indeed, be a special phenotype.

\section{Conclusions}

The key issue of this essay is how it is possible that a mere 40 alveolar epithelial type I cells can form a very thin and viable lining of $95 \%$ of the surface of an average human alveolus. The area covered by one epithelial cell is four times larger than that of a capillary endothelial cell that serves the same function, namely, to make a very thin air-blood barrier. We found that this is achieved, while still ensuring viability, by allowing the cell to branch and form four or more cytoplasmic lining units ("epithelial plates") that are all 


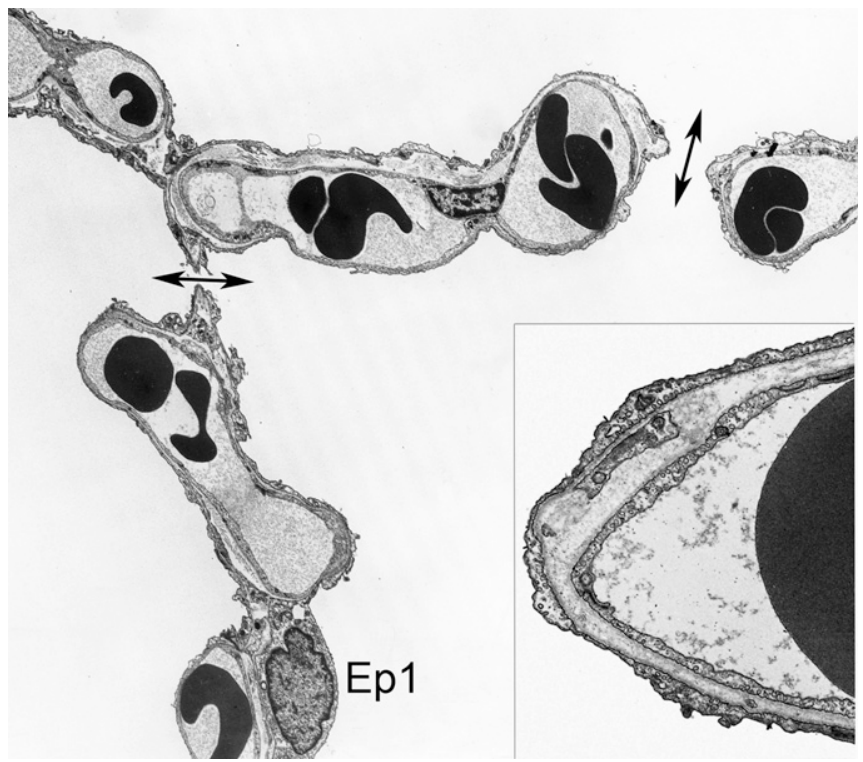

Figure 9. Alveolar septa from dog lung with one type I cell (Ep1) and two alveolar pores (doubleheaded arrows). Inset shows lining of pore edge by type I cell leaflet that extends into both alveoli. connected to the nucleus by cytoplasmic stalks, and this is because the type I cell can criss-cross the alveolar septum through gaps in the matrix: the basal cell membrane of the cell is one continuum attached to an undivided epithelial

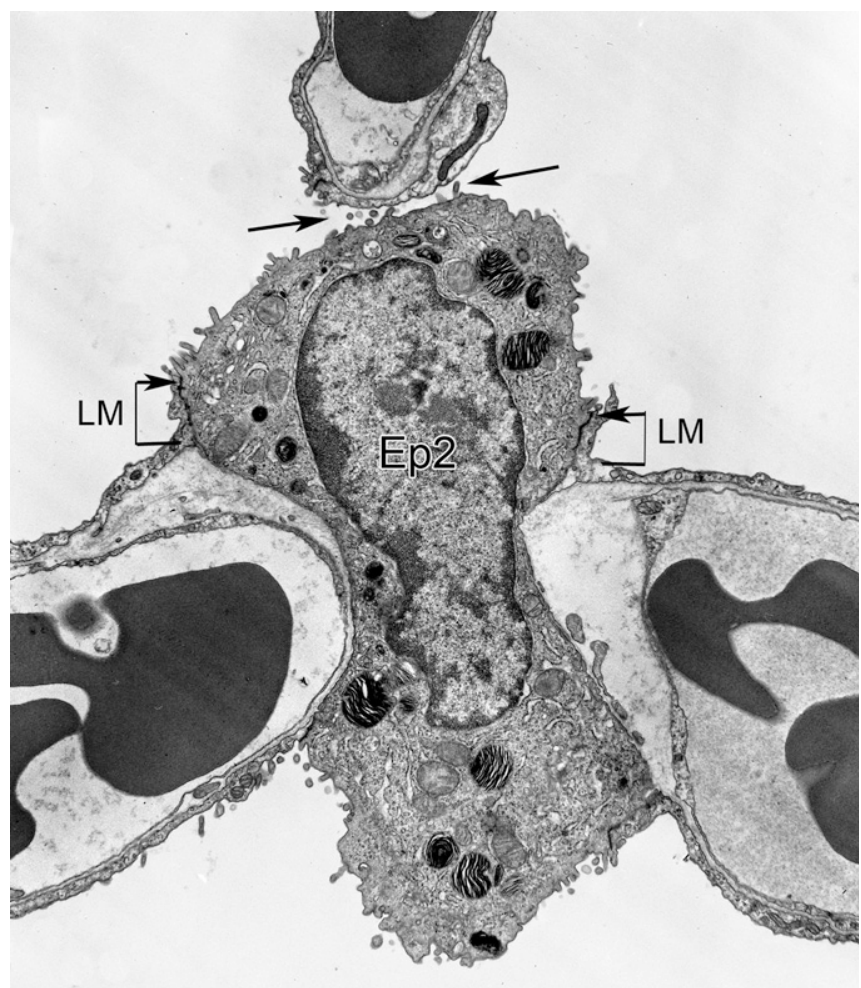

Figure 10. Alveolar type II cell (Ep2) that sits in the junction of three alveolar septa and at the edge of an alveolar pore (paired long arrows). Its two apical plates with microvilli are exposed to the lower alveolus as well as to the two alveoli connected by the pore. LM marks the extended lateral membranes of type I cells where joined to a type II cell, with terminal bar at the top (short arrows). Rat lung. Reprinted by permission from Reference 24. basement membrane. This allows the maintenance of viability, despite a very large surface expanse, by keeping the cytoplasmic traffic pathways short, similar to that of capillary endothelial cells, but this at the expense of having lost the ability to proliferate by cell division.

This raises a number of questions that need to be explored:

(1) Are there other cell types that share this property? One could think of neurons in the brain or also of some of the glial cells, such as the oligodendrocytes that form myelin sheaths around several axons. These cells are also terminal cells that must be replenished from stem cells. Do they have anything in common with the type I cells? How is the loss of proliferative capacity determinedgenetic or opportunistic?

(2) In view of the attempts to design a "lung on the chip" (56-58), how important is the design of the substrate that, in nature, is a porous matrix sheet that allows the cells to criss-cross the septum and line both sides of the capillary network? What are the limits of studying these cells on flat, closed substrates?

(3) How does the bourgeoning cytoplasmic stalk of a type I cell pushing across the matrix meet the type I cell on the other side to make a confluent epithelial lining? How important is the continuity of the epithelial basement membrane in this process? Much could be learned here by studying how this cellular complexity arises during lung growth where new type I cells must also arise from dividing type II cells (52).

Answers to these questions could help us understand what special conditions must be met to permit the building of an extremely thin yet robust alveolar epithelial barrier of extraordinary architectural complexity. Such insights may also be valuable for designing new in vitro systems for molecular cell studies or as "lung-on-achip" devices.

Author disclosures are available with the text of this article at www.atsjournals.org.

Acknowledgment: The author acknowledges the help received from Barbara Krieger and Dr. Stefan Tschanz in the preparation of this essay. 


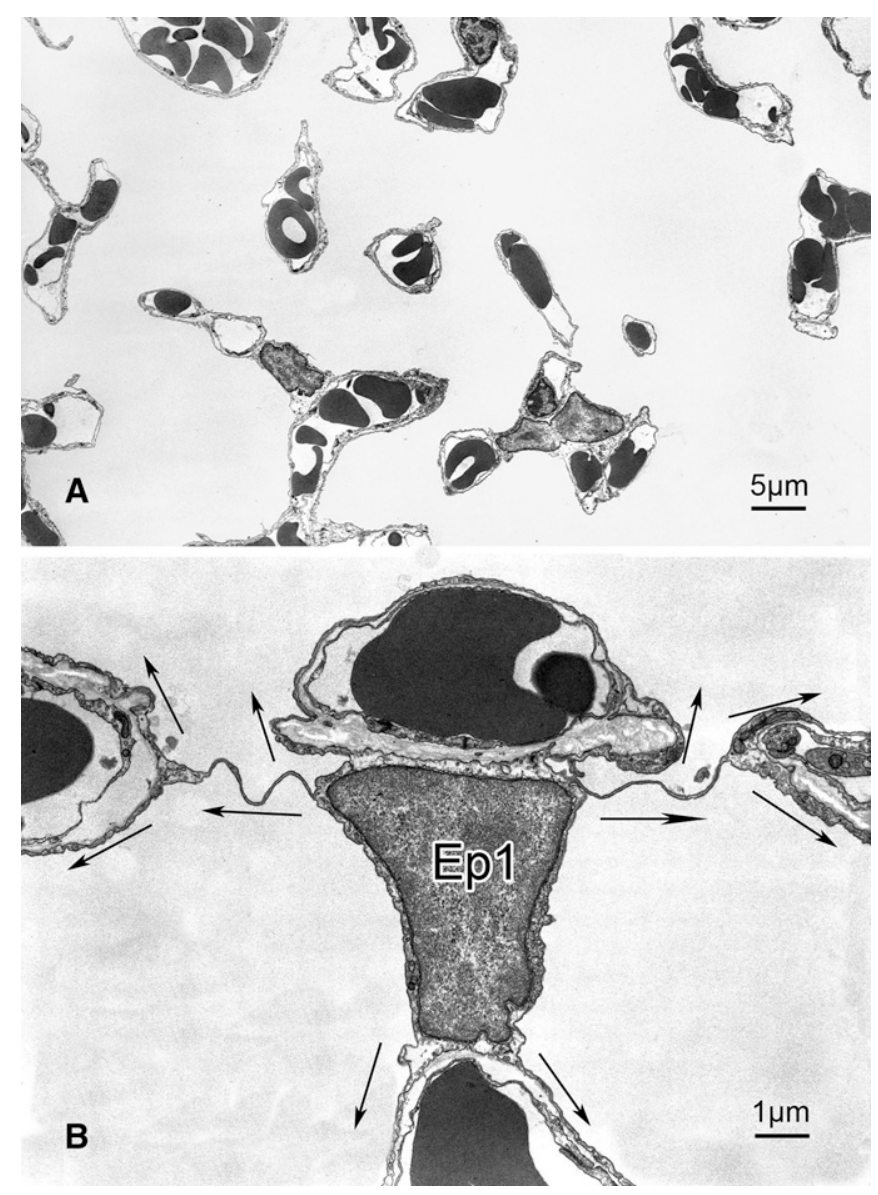

Figure 11. Lung of the Etruscan shrew. (A) Low-power electron micrograph shows very high density of capillaries in parenchymal air space; alveoli are difficult to make out on a thin section. Scale bar $=5 \mu \mathrm{m}$. (B) Type I cell (Ep1) sits in capillary niche at the junction of three septa and forms complex branching into multiple cytoplasmic leaflets (arrows). The air-blood barrier is extremely thin. Scale bar $=1 \mu \mathrm{m}$.

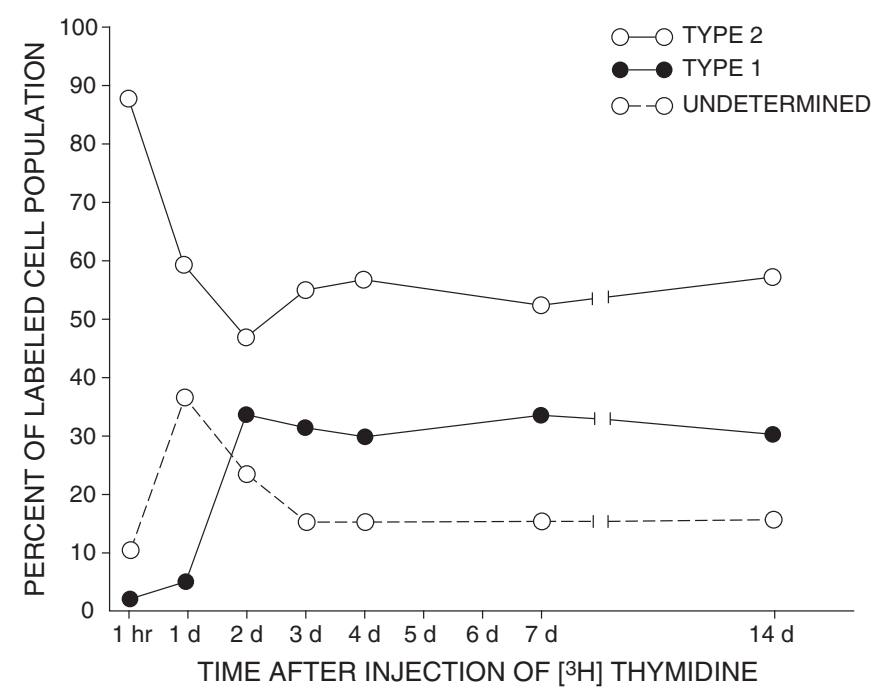

Figure 12. Kinetics of the transformation of type II into type I cells in rats that had been slightly damaged by $\mathrm{NO}_{2}$ exposure before injection of tritiated thymidine to mark cells preparing for mitosis. At 1 hour after injection, only type II cells are marked. Marked type I cells increase after 2 days in parallel with the fall in number of labeled type II cells as a result of transdifferentiation of the newly formed type II cells into type I cells. Reprinted by permission from Reference 49. 


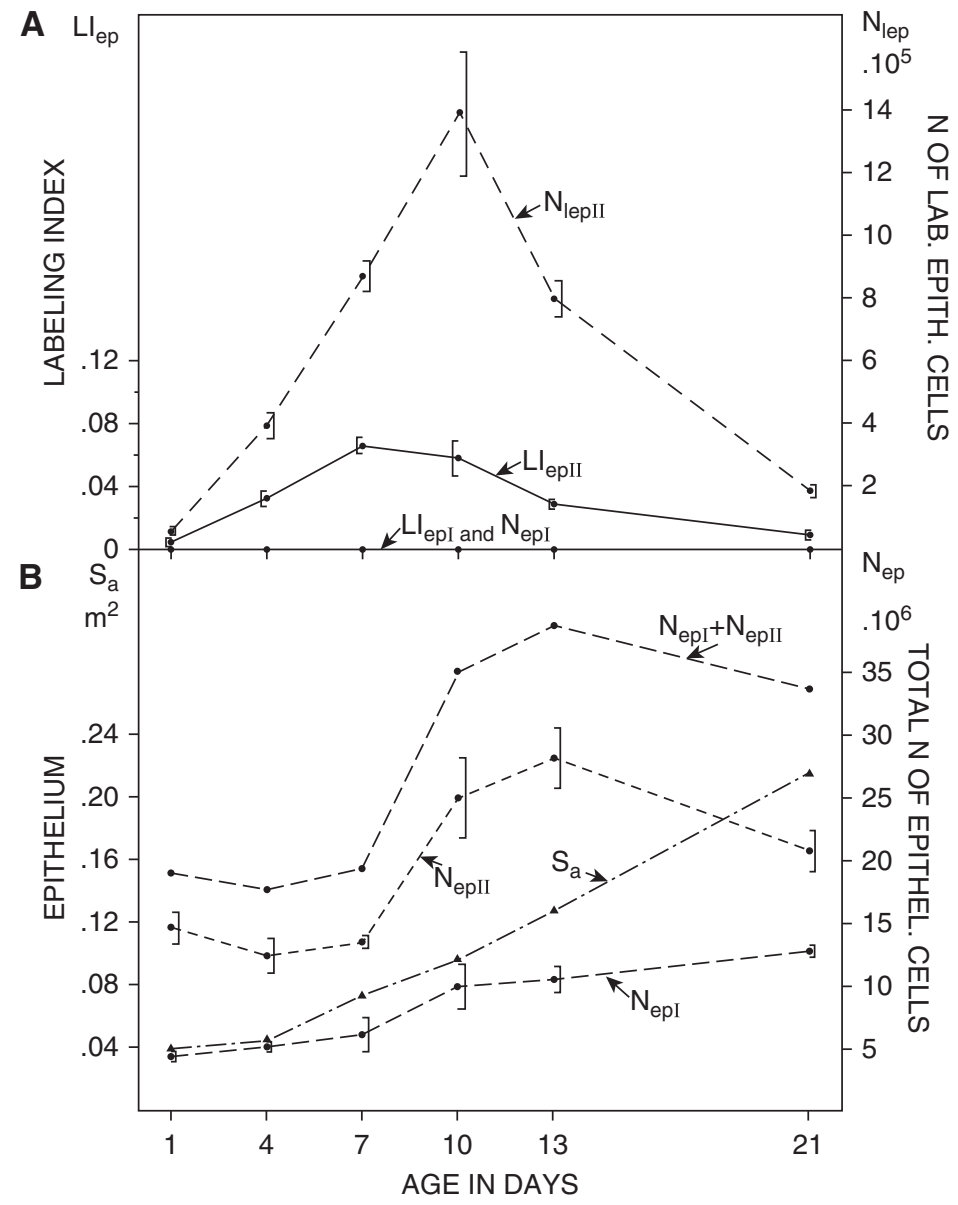

Figure 13. Cell kinetics in postnatal rat lungs shown by thymidine labeling of cells going into mitosis. (A) Only type II cells were labeled with labeling index highest between Postnatal Days 7 and 14; none of the type I cells were labeled. $(B)$ The number of type I cells increased steadily as type II cells proliferated and transformed into type I cells. At Day 21, there were twice as many type II cells corresponding to the normal ratio of the two cell types. Note that the alveolar surface increases more steeply than the number of type I cells between Days 13 and 21 , suggesting that the individual cells expanded the area they covered. ep = epithelium; epl = type I cell; epll = type II cell; lep = labeled epithelial cells; lep II = labeled type II cells; LI = labeling index; $\mathrm{N}=$ number of cells; $\mathrm{S}_{\mathrm{a}}=$ alveolar surface area. Reprinted by permission from Reference 52.

\section{References}

1. Weibel ER. It takes more than cells to make a good lung. Am J Respir Crit Care Med 2013;187:342-346.

2. Weibel ER. What makes a good lung? Swiss Med Wkly 2009;139: 375-386.

3. Gehr P, Bachofen M, Weibel ER. The normal human lung: ultrastructure and morphometric estimation of diffusion capacity. Respir Physiol 1978;32:121-140.

4. Dobbs LG, Johnson MD, Vanderbilt J, Allen L, Gonzalez R. The great big alveolar TI cell: evolving concepts and paradigms. Cell Physiol Biochem 2010;25:55-62.

5. Borok Z. Alveolar epithelium: beyond the barrier. Am J Respir Cell Mol Biol 2014;50:853-856.

6. Borok Z, Crandall ED. More life for a "terminal" cell. Am J Physiol Lung Cell Mol Physiol 2009;297:L1042-L1044.

7. Demaio L, Tseng W, Balverde Z, Alvarez JR, Kim KJ, Kelley DG, Senior RM, Crandall ED, Borok Z. Characterization of mouse alveolar epithelial cell monolayers. Am J Physiol Lung Cell Mol Physiol 2009; 296:L1051-L1058.

8. Flodby P, Borok Z, Banfalvi A, Zhou B, Gao D, Minoo P, Ann DK, Morrisey EE, Crandall ED. Directed expression of Cre in alveolar epithelial type 1 cells. Am J Respir Cell Mol Biol 2010;43:173-178.
9. Johnson MD, Widdicombe JH, Allen L, Barbry P, Dobbs LG. Alveolar epithelial type I cells contain transport proteins and transport sodium, supporting an active role for type I cells in regulation of lung liquid homeostasis. Proc Natl Acad Sci USA 2002;99:1966-1971.

10. Barkauskas CE, Cronce MJ, Rackley CR, Bowie EJ, Keene DR, Stripp BR, Randell SH, Noble PW, Hogan BL. Type 2 alveolar cells are stem cells in adult lung. $J$ Clin Invest 2013;123: 3025-3036.

11. Chapman HA, Li X, Alexander JP, Brumwell A, Lorizio W, Tan K, Sonnenberg A, Wei Y, Vu TH. Integrin $\alpha 6 \beta 4$ identifies an adult distal lung epithelial population with regenerative potential in mice. $J$ Clin Invest 2011;121:2855-2862.

12. Desai TJ, Brownfield DG, Krasnow MA. Alveolar progenitor and stem cells in lung development, renewal and cancer. Nature 2014;507: 190-194.

13. Wang J, Edeen K, Manzer R, Chang Y, Wang S, Chen X, Funk CJ, Cosgrove GP, Fang X, Mason RJ. Differentiated human alveolar epithelial cells and reversibility of their phenotype in vitro. Am J Respir Cell Mol Biol 2007;36:661-668.

14. Eberth CJ. Ueber den feineren Bau der Lunge. Zwiss Zoologie 1862;12: 1-32.

15. Policard A. Les nouvelles idées sur la disposition de la surface respiratoire pulmonaire. Presse Med 1929;80:1-20. 
16. Low FN. The pulmonary alveolar epithelium of laboratory mammals and man. Anat Rec 1953;117:241-263.

17. Policard A, Collet A, Pregermain S. Research with the electron microscope on the parietal alveolar cells of the lung of mammals [in French]. Z Zellforsch Mikrosk Anat 1959;50:561-587.

18. Mason RJ, Shannon J. Alveolar type II cells. In: Crystal RG, West JB, Weibel ER, Barnes PJ, editors. The lung: scientific foundations, 2nd ed. Vol. 1. Philadelphia: Lippincott-Raven Publishers; 1997. pp. 543-555.

19. Hawgood S. Surfactant protein B: structure and function. Biol Neonate 2004;85:285-289.

20. Ochs M, Johnen G, Müller KM, Wahlers T, Hawgood S, Richter J, Brasch F. Intracellular and intraalveolar localization of surfactant protein $\mathrm{A}(\mathrm{SP}-\mathrm{A})$ in the parenchymal region of the human lung. Am J Respir Cell Mol Biol 2002;26:91-98.

21. Danto SI, Shannon JM, Borok Z, Zabski SM, Crandall ED. Reversible transdifferentiation of alveolar epithelial cells. Am J Respir Cell Mol Biol 1995;12:497-502.

22. Li G, Flodby P, Luo J, Kage H, Sipos A, Gao D, Ji Y, Beard LL, Marconett CN, DeMaio L, et al. Knockout mice reveal key roles for claudin 18 in alveolar barrier properties and fluid homeostasis. Am J Respir Cell Mol Biol 2014;51:210-222.

23. Crapo JD, Barry BE, Gehr P, Bachofen M, Weibel ER. Cell number and cell characteristics of the normal human lung. Am Rev Respir Dis 1982;126:332-337.

24. Kölliker A. Zur Kenntnis des Baues der Lunge des Menschen. Verh Phys-Med Ges Würzburg 1881;16:1-24.

25. Weibel ER. The mystery of "non-nucleated plates" in the alveolar epithelium of the lung explained. Acta Anat (Basel) 1971;78: 425-443.

26. Weibel ER, Bachofen $\mathrm{H}$. The fiber scaffold of lung parenchyma. In: Crystal RG, West JB, Weibel ER, Barnes PJ, editors. The lung: scientific foundations, 2nd ed. Vol. 1. Philadelphia: Lippincott-Raven Publishers; 1997. pp. 1139-1146.

27. Burri PH. Structural aspects of postnatal lung development-alveolar formation and growth. Biol Neonate 2006;89:313-322.

28. Burri PH. Fetal and postnatal development of the lung. Annu Rev Physiol 1984;46:617-628.

29. Zeltner TB, Burri PH. The postnatal development and growth of the human lung. II. Morphology. Respir Physiol 1987;67:269-282.

30. Watanabe-Takano H, Takano K, Sakamoto A, Matsumoto K, Tokuhisa T, Endo T, Hatano M. DA-Raf-dependent inhibition of the Ras-ERK signaling pathway in type 2 alveolar epithelial cells controls alveolar formation. Proc Natl Acad Sci USA 2014;111: E2291-E2300.

31. Weibel ER. How to make an alveolus. Eur Respir J 2008;31:483-485.

32. Burri PH. The postnatal growth of the rat lung: 3. Morphology. Anat Rec 1974;180:77-98.

33. Yurchenco PD. Basement membranes: cell scaffoldings and signaling platforms. Cold Spring Harb Perspect Biol 2011;3:a004911.

34. Lee JL, Streuli CH. Integrins and epithelial cell polarity. J Cell Sci 2014; 127:3217-3225.

35. Rodriguez-Fraticelli AE, Martin-Belmonte F. Picking up the threads: extracellular matrix signals in epithelial morphogenesis. Curr Opin Cell Biol 2014;30C:83-90.

36. Ngok SP, Lin WH, Anastasiadis PZ. Establishment of epithelial polarity-GEF who's minding the GAP? J Cell Sci 2014;127: 3205-3215

37. Crapo JD, Young SL, Fram EK, Pinkerton KE, Barry BE, Crapo RO. Morphometric characteristics of cells in the alveolar region of mammalian lungs. Am Rev Respir Dis 1983;128:S42-S46.
38. Haies DM, Gil J, Weibel ER. Morphometric study of rat lung cells. I. Numerical and dimensional characteristics of parenchymal cell population. Am Rev Respir Dis 1981;123:533-541.

39. Stone KC, Mercer RR, Gehr P, Stockstill B, Crapo JD. Allometric relationships of cell numbers and size in the mammalian lung. Am J Respir Cell Mol Biol 1992;6:235-243.

40. Weibel ER. Morphological basis of alveolar-capillary gas exchange. Physiol Rev 1973;53:419-495.

41. Weibel ER, Federspiel WJ, Fryder-Doffey F, Hsia CC, König M, StalderNavarro V, Vock R. Morphometric model for pulmonary diffusing capacity. I. Membrane diffusing capacity. Respir Physiol 1993;93: 125-149.

42. Gehr P, Sehovic S, Burri PH, Claassen H, Weibel ER. The lung of shrews: morphometric estimation of diffusion capacity. Respir Physiol 1980;40:33-47.

43. Weibel ER, Claassen H, Gehr P, Sehovic S, Burri PH. The respiratory system of the smallest mammal. In: Schmidt-Nielsen K, Bolis L, Taylor CR, editors. Comparative physiology: primitive mammals. Cambridge: Cambridge University Press; 1980. pp. 181-191.

44. Weibel ER. The pathway for oxygen. Structure and function in the mammalian respiratory system. Cambridge, MA: Harvard University Press; 1984.

45. Kapanci Y, Weibel ER, Kaplan HP, Robinson FR. Pathogenesis and reversibility of the pulmonary lesions of oxygen toxicity in monkeys. II. Ultrastructural and morphometric studies. Lab Invest 1969;20: 101-118.

46. Kistler GS, Caldwell PR, Weibel ER. Development of fine structural damage to alveolar and capillary lining cells in oxygen-poisoned rat lungs. J Cell Biol 1967;32:605-628.

47. Bachofen M, Weibel ER. Alterations of the gas exchange apparatus in adult respiratory insufficiency associated with septicemia. Am Rev Respir Dis 1977;116:589-615.

48. Bachofen M, Weibel ER. Basic pattern of tissue repair in human lungs following unspecific injury. Chest 1974;65:14S-19S.

49. Evans MJ, Cabral LJ, Stephens RJ, Freeman G. Transformation of alveolar type 2 cells to type 1 cells following exposure to $\mathrm{NO}_{2}$. Exp Mol Pathol 1975;22:142-150.

50. Adamson IY, Bowden DH. The type 2 cell as progenitor of alveolar epithelial regeneration: a cytodynamic study in mice after exposure to oxygen. Lab Invest 1974;30:35-42.

51. Adamson IY, Bowden DH. Derivation of type 1 epithelium from type 2 cells in the developing rat lung. Lab Invest 1975;32:736-745.

52. Kauffman SL, Burri PH, Weibel ER. The postnatal growth of the rat lung II. Autoradiography. Anat Rec 1974;180:63-76.

53. Rock JR, Hogan BL. Epithelial progenitor cells in lung development, maintenance, repair, and disease. Annu Rev Cell Dev Biol 2011;27: 493-512.

54. Baker J, Garrod D. Epithelial cells retain junctions during mitosis. J Cell Sci 1993;104:415-425.

55. Weibel ER. A note on differentiation and divisibility of alveolar epithelial cells. Chest 1974;65:19S-21S.

56. Ott HC, Clippinger B, Conrad C, Schuetz C, Pomerantseva I, Ikonomou L, Kotton D, Vacanti JP. Regeneration and orthotopic transplantation of a bioartificial lung. Nat Med 2010;16:927-933.

57. Huh D, Leslie DC, Matthews BD, Fraser JP, Jurek S, Hamilton GA, Thorneloe KS, McAlexander MA, Ingber DE. A human disease model of drug toxicity-induced pulmonary edema in a lung-on-a-chip microdevice. Sci Transl Mede 2012;4:159ra147.

58. Wagner DE, Bonvillain RW, Jensen T, Girard ED, Bunnell BA, Finck CM Hoffman AM, Weiss DJ. Can stem cells be used to generate new lungs? Ex vivo lung bioengineering with decellularized whole lung scaffolds. Respirology 2013;18:895-911. 